\title{
Exploring Linguistic Interdependence between American Sign Language and English through Correlational and Multiple Regression Analyses of the Abilities of Biliterate Deaf Adults
}

\author{
Melissa M. Ausbrooks ${ }^{1,2}$, Mary Anne Gentry ${ }^{3} \&$ Gabriel A. Martin ${ }^{3}$ \\ ${ }^{1}$ Research \& Instruction, Mississippi School for the Deaf, Jackson, Mississippi, USA \\ ${ }^{2}$ Speech \& Hearing Science, University of Southern Mississippi, Hattiesburg, Mississippi, USA \\ ${ }^{3}$ Department of Deaf Studies and Deaf Education, Lamar University, Beaumont, Texas, USA \\ Correspondence: Melissa Ausbrooks, Mississippi School for the Deaf, 1253 Eastover Drive, Jackson, Mississippi \\ 39216, USA. Tel: 1-601-984-8103. E-mail: mausbrooks@mde.k12.ms.us
}

Received: October 7, 2013 Accepted: December 6, 2013 Online Published: January 23, 2014

doi:10.5539/ijel.v4n1p1 URL: http://dx.doi.org/10.5539/ijel.v4n1p1

\begin{abstract}
The purpose of this study was to explore issues of linguistic interdependence between American Sign Language (ASL) and English within the context of reading comprehension skills among thirty-two bilingual Deaf (Note 1) adults. By synthesizing findings within existing literature, a prediction model of reading comprehension was developed. Researchers investigated whether or not the threshold hypothesis and linguistic interdependence theory (Cummins, 1976, 1979, 1981, 2003) could be generalizable to bimodal bilinguals. Researchers investigated relationships among six instructional constructs and several environmental variables thought to be predictor variables for reading comprehension. Statistically significant findings included the identification of ten relationships among instructional predictors and five relationships regarding environmental factors. Statistically significant relationships are presented and implications for the generalizability of linguistic interdependence for bimodal bilinguals are summarized. Results of this study suggest that both the threshold hypothesis and linguistic interdependence theory are both generalizable to ASL and English, despite linguistic incongruency. Specific proficiencies transferred among ASL Morphology and English Reading Vocabulary, ASL Morphology and English Reading Comprehension, and ASL Semantics and English Language Mechanics.
\end{abstract}

Keywords: deaf, deaf education, bilingual, American sign language, ASL, reading comprehension, linguistic interdependence

\section{Introduction}

\subsection{Introduction and Importance of the Problem}

Deaf persons who use American Sign Language (ASL) while performing English literacy tasks must use a translation process to exhibit reading comprehension skill (Andrews \& Mason, 1991; Andrews, Winograd, \& DeVille, 1994; Lartz \& Lestina, 1995). For these readers, ASL is the medium by which they discuss, analyze, and mediate the linguistic information found in English source texts (Kuntze, 2004; Wilbur, 2000). In addition to decoding words, they must identify syntactic markers, semantic intention, and pragmatic nuances (Hansen \& Mosqueria, 1996). Through a process of semantic analysis, the reader must then create an equivalent, accurately-expressed message in ASL (Simms, Andrews, \& Smith, 2005). They must embed the writer's intention within prosodic features (Hansen \& Mosqueria, 1996). Learning to read English using this type of approach is extremely difficult (Bailes, 2001). Sophisticated codeswitching strategies must be applied to concurrently engage both languages (Bailes, 2001; Chamberlain \& Mayberry, 2000; Padden \& Ramsey, 1998). Metalinguistic awareness of both languages is therefore necessitated to attain functional English literacy (Livingston, 1997; Nover \& Andrews, 1998).

\subsection{Relevant Scholarship}

Despite this challenge, there is an ongoing effort to promote an ASL/English bilingual instructional model (Andrews, Ferguson, Roberts, \& Hodges, 1997; DeLana, Gentry, \& Andrews, 2007; Nover, Andrews, Baker, Everhart, \& Bradford, 2002). In this model, ASL is considered a valued and irreplaceable tool necessary for 
English literacy instruction (Nover, Christensen, \& Cheng, 1998). Supporters argue that benefits surround the methodology's ability to capitalize on deaf children's full linguistic repertoire (Nover, 2006). While the methodology is still in its early stages of development, studies that show statistically significant relationships between ASL and English are moving the approach forward. See Table 1. The specific manner in which bilingual deaf children utilize their linguistic abilities during the reading process, however, remains a puzzle (Chamberlain \& Mayberry, 2000; Padden \& Hanson, 2000). Explanations have been relegated to theoretical claims rather than evidence-driven understandings (Schirmer, 2001; Wilbur, 2000). Consequently, the methodological option is not without controversy. Opponents argue that the linguistic codes of ASL and English are so fundamentally different that claims of language interdependence are premature, at best (Mayer \& Akumatsu, 2003; Mayer \& Wells, 1996). Both sides do agree that literacy lies locked within multifaceted language issues, but debate continues regarding ASL's place in English literacy instruction (Chamberlain, Morford, \& Mayberry, 2000; Luetke-Stahlman, 1990; Marschark, 2000; Marschark, Siple, Martin, Campbell, \& Everhart, 1997). Therefore, it is paramount to investigate how deaf and hard of hearing individuals, who identify themselves as ASL/English bilinguals, utilize their ASL knowledge to assist with English literacy tasks.

Table 1. Empirical studies investigating relationships between ASL and English

\begin{tabular}{lcl}
\hline Study & N & Results \\
\hline $\begin{array}{l}\text { Moores et al. (1987, } \\
\text { 1990) }\end{array}$ & 130 & $\begin{array}{l}\text { Found non-significant relationships between ASL language proficiency } \\
\text { interviews and a composite of five standardized English reading measures for } \\
\text { students age 16-18. }\end{array}$ \\
\hline $\begin{array}{l}\text { Mayberry (1989); } \\
\begin{array}{l}\text { Mayberry et al. } \\
(1994, \text { 1999) }\end{array}\end{array}$ & $\begin{array}{l}\text { Found statistically significant relationships between ASL and English story } \\
\text { comprehension measures; ASL story comprehension and SAT Reading scores; } \\
\text { ASL sentence span and English story comprehension. }\end{array}$ \\
\hline $\begin{array}{l}\text { Andrews, Winograd, } \\
\text { and Deville (1994) }\end{array}$ & 7 & $\begin{array}{l}\text { Tested the effectiveness of using ASL summaries for retellings of English } \\
\text { fables. The quantity and quality of information in retellings clearly improved- }\end{array}$ \\
\hline $\begin{array}{l}\text { Andrews, Ferguson, } \\
\text { Roberts, and Hodges } \\
(1997)\end{array}$ & 7 & $\begin{array}{l}\text { Bilingual-Bicultural programming had a significant positive impact on PK-1st } \\
\text { grade students in Basic Concepts, Auditory Comprehension, Picture }\end{array}$ \\
& $\begin{array}{l}\text { Vocabulary, English Grammar, Reading, ASL Competency, English Writing } \\
\text { Tasks, and Mathematics. }\end{array}$ \\
\hline $\begin{array}{l}\text { Hoffmeister, Philip, } \\
\text { Costello, and Grass } \\
(1997)\end{array}$ & 81 & $\begin{array}{l}\text { Administered the ASL Assessment Instrument (ASLAI), the Stanford } \\
\text { Achievement Test, and the Rhode Island Test of Language Structure (RITLS). } \\
\text { Identified statistically significant correlations between Age, RITLS scores, } \\
\text { SAT Reading scores, ASL Comprehension scores, and ASL Production scores. }\end{array}$ \\
\hline
\end{tabular}

\begin{tabular}{lll}
\hline $\begin{array}{l}\text { Prinz and Strong } \\
\text { (1998); Strong and }\end{array}$ & 155 & $\begin{array}{l}\text { Statistically significant correlations between ASL proficiency and English } \\
\text { literacy students with deaf mothers only outperformed students with hearing } \\
\text { Prinz (1997, 2000) }\end{array}$ \\
mothers with low ASL ability.
\end{tabular}

Padden and Ramsey (1998)

31
ASL tests correlated with reading comprehension, despite parental hearing status. Discovered a relationship between reading skills and ASL sentence order, ASL verb agreement, ASL sentence imitation, fingerspelling, and initialized signs.

Schimmel, Edwards, and Pritchett (1999)

48 Conducted an impact study of the Fairview reading program. The reading program had five components: Phonemic Awareness, Adapted Dolch Words, Bridge Lists and Bridging, Reading Comprehension, and ASL Development via language experience stories. An impact analysis showed marked improvement in all areas.

\begin{tabular}{lll}
\hline $\begin{array}{l}\text { Hoffmeister } \\
(2000)\end{array}$ & 78 & $\begin{array}{l}\text { A relationship between ASL knowledge and specific reading skills was } \\
\text { observed. Students with extensive ASL exposure scored better on ASL and } \\
\text { reading comprehension tasks }\end{array}$ \\
\hline
\end{tabular}

Nover, Andrews, Baker, Everhart, and Bradford (2002)
122 Students with ASL/English bilingual trained teachers significantly improved English Vocabulary and Language subtest scores. Younger students (8-12) scored significantly higher than national norms for Vocabulary, Reading 


\begin{tabular}{lll}
\hline & Comprehension, and Language subtests- \\
\hline Rittenhouse, Jenkins, 11 & $\begin{array}{l}\text { Introduced stories in Signed English and ASL, The average correct responses } \\
\text { and Dancer (2002) }\end{array}$ & $\begin{array}{l}\text { for stories told in ASL were 47\% and in Signed English, 25\%. When ASL was } \\
\text { used, students were more enthusiastic about the stories and responses to } \\
\text { questions were more often correct, demonstrating greater story } \\
\text { comprehension. }\end{array}$
\end{tabular}

\begin{tabular}{lcl}
\hline $\begin{array}{l}\text { DeLana (2004); } \\
\text { DeLana, Gentry, and } \\
\text { Andrews (2007) }\end{array}$ & 25 & $\begin{array}{l}\text { ASL/English bilingual education effectively implemented in a public school } \\
\text { setting. Relationship between reading comprehension achievement and years } \\
\text { of ASL usage found to be statistically significant. }\end{array}$ \\
\hline Kuntze (2004) & 91 & $\begin{array}{l}\text { Levels of ASL passage comprehension had significant predictive power of } \\
\text { English passage comprehension. Significant differences in ASL and English } \\
\text { literacy skills of DCDP and DCHP. }\end{array}$ \\
\hline Li (2005) & 15 & $\begin{array}{l}\text { Student retelling scores and understanding of science concepts significantly } \\
\text { increased with the use of PVR, a bilingual technique. Deaf bilingual students } \\
\text { experienced statistically significant gains compared to hearing bilingual } \\
\text { students. }\end{array}$ \\
\hline Smith (2007) & 123 & $\begin{array}{l}\text { Students with higher English reading comprehension scores on the Stanford } \\
\text { Achievement Test also scored better on ASL phonology, morphology, syntax, } \\
\text { semantic, and pragmatic tasks on the TASL-R. This relationship was } \\
\text { statistically significant. }\end{array}$ \\
\hline Geeslin (2007) & $\begin{array}{l}\text { Examined the impact of the bilingual programming on academic performance } \\
\text { of students at the Indiana School for the Deaf. Considered Reading } \\
\text { Comprehension and Total Language subtests of the SAT-HI. A significant } \\
\text { reduction was found in the gap between the academic performance of deaf } \\
\text { children of deaf parents and deaf children of hearing parents. }\end{array}$ \\
\hline Andrews and Rusher & $\begin{array}{l}\text { Results of four studies are examined that suggest that certain codeswitching } \\
\text { strategies support English vocabulary learning and reading comprehension. } \\
\text { These instructional strategies are couched in a five-pronged approach to } \\
\text { furthering the development of bilingual education for deaf students. }\end{array}$ \\
\hline Myers (2011) & $\begin{array}{l}\text { Examined the impact of bilingual programming on academic performance of } \\
\text { students at the Texas School for the Deaf. Considered Reading } \\
\text { Comprehension scores on the Stanford 10. Found moderate correlations } \\
\text { between time variables (age when tested, age when enrolled, and number of } \\
\text { years spent in a residential school) and performance on the SAT-10 Reading } \\
\text { Comprehension Subtest }\end{array}$ \\
\hline &
\end{tabular}

\subsection{Hypothesis and Correspondence to Research Design}

Researchers hypothesized that the threshold hypothesis and linguistic interdependence theory applied to ASL and English, despite linguistic distance and modal differences. Researchers determined to explore potential interdependence by engaging bimodal bilinguals, who were Deaf, in reading tasks, since this requires engagement of both languages concurrently. A prediction model was created for this study, placing predictors of reading comprehension within a language interdependence context. See Figure 1. Reading Success, is defined as comprehension of source text and considered the criterion variable for the study. Six predictor variables were extrapolated from major findings in the reviewed studies. Academic Knowledge is defined here as core of knowledge that is used for academic functioning. ASL Skill and English Skill encompass phonology, morphology, syntax, semantics, pragmatics, prosody, and vocabulary for each language respectively. Metalinguistic awareness of ASL and English denotes the individual's knowledge and skill regarding the languages he or she uses and the foundation for linguistic study. Metacognitive skills and strategies refer to the awareness of thought processes during reading as well as the self-monitoring of comprehension. Reading Translation Skill refers to the ability to accurately translate from an English source text to ASL at a developmentally-appropriate level. 


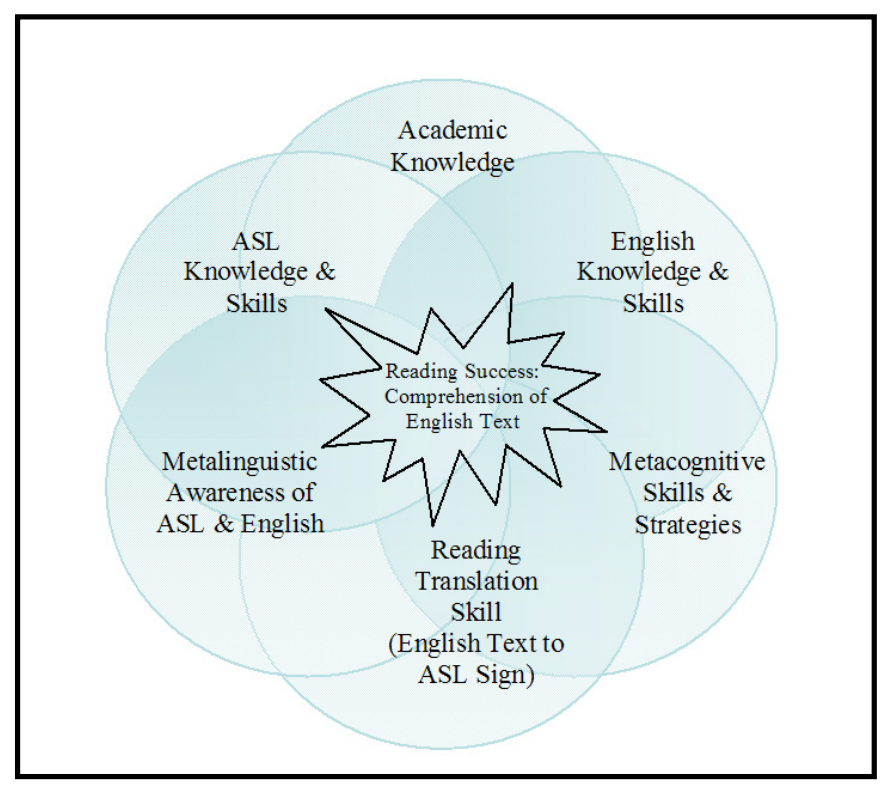

Figure 1. Potential model of predictors for reading success

\section{Method}

The researcher investigated relationships among six instructional constructs and several environmental variables thought to be predictors for reading comprehension. A non-experimental, basic research design using correlational methodology and multiple regression analysis was utilized. The Pearson $r$ product moment of correlation coefficient was determined for all scaled data. The phi coefficient $(\Phi)$ was determined for all nominal data that could be arranged in $2 \times 2$ dichotomous pairs. A multiple regression analyses using stepwise selection methods was conducted, with the Stanford 10 Reading Comprehension being the criterion variable.

\subsection{Sampling Procedures and Participants}

This focused study utilized a purposive, convenient, snowball sample of Deaf adults. Participants were solicited primarily from Lamar University in Beaumont, Texas and its surrounding communities. Selection criteria included presence of significant hearing loss, daily use of American Sign Language, and daily use of English. Thirty-five individuals consented to participate but only thirty-two were able to complete minimum requirements. The resulting sample included these 32 participants.

\subsubsection{Environmental Demographics of Participants}

Understanding participant demographics is imperative in accurately interpreting findings. Researchers in this study chose to consider bimodal bilingual adults who were Deaf. The researcher investigated language use among this group for two reasons. First, they were thought to be balanced bilinguals, similarly proficient in both ASL and English. Secondly, they held unique understanding of language issues as their collegiate backgrounds included an intense focus on ASL/English bilingual methodology. Their specific environmental demographics are outlined in Tables 2-5. 
Table 2. Personal characteristics

\begin{tabular}{|c|c|c|}
\hline Demographic Characteristic & \# & $\%$ \\
\hline \multicolumn{3}{|l|}{ Age } \\
\hline $18-25$ & 5 & $16 \%$ \\
\hline $26-35$ & 15 & $47 \%$ \\
\hline $36-50$ & 9 & $28 \%$ \\
\hline $50+$ & 3 & $9 \%$ \\
\hline \multicolumn{3}{|l|}{ Educational Background (Earned or in Progress) } \\
\hline Bachelor Degree & 31 & $97 \%$ \\
\hline Master Degree & 28 & $88 \%$ \\
\hline Doctoral Degree & 2 & $6 \%$ \\
\hline \multicolumn{3}{|l|}{ Ethnicity } \\
\hline African American & 3 & $9 \%$ \\
\hline Asian & 2 & $6 \%$ \\
\hline Hispanic & 3 & $9 \%$ \\
\hline Multiracial & 1 & $3 \%$ \\
\hline White & 23 & $72 \%$ \\
\hline \multicolumn{3}{|l|}{ Etiology } \\
\hline Illness & 11 & $34 \%$ \\
\hline Complications during Pregnancy & 4 & $13 \%$ \\
\hline Genetic & 5 & $16 \%$ \\
\hline Unknown & 12 & $38 \%$ \\
\hline \multicolumn{3}{|l|}{ Age of Onset of Deafness } \\
\hline Birth to Age 2 & 27 & $84 \%$ \\
\hline Age 2 to Age 4 & 1 & $3 \%$ \\
\hline Age 4 to Age 6 & 1 & $3 \%$ \\
\hline Age 6 to Age 12 & 1 & $3 \%$ \\
\hline Age $12+$ & 2 & $6 \%$ \\
\hline \multicolumn{3}{|l|}{ Level of Hearing Loss } \\
\hline Mild to Moderate & 4 & $13 \%$ \\
\hline Severe & 7 & $22 \%$ \\
\hline Profound & 21 & $66 \%$ \\
\hline \multicolumn{3}{|l|}{ Presence of Additional Disabilities } \\
\hline Visual Impairment & 1 & $3 \%$ \\
\hline \multicolumn{3}{|l|}{ Presence of Deaf Parents } \\
\hline 1 or More Deaf Parents & 7 & $22 \%$ \\
\hline No Deaf Parents & 25 & $78 \%$ \\
\hline \multicolumn{3}{|l|}{ Presence of Deaf Siblings } \\
\hline 1 or More Deaf Siblings & 9 & $28 \%$ \\
\hline No Deaf Siblings & 23 & $72 \%$ \\
\hline \multicolumn{3}{|l|}{ Presence of Other Deaf Relatives } \\
\hline 1 or More Deaf Relatives & 9 & $28 \%$ \\
\hline No Deaf Relative & 23 & $72 \%$ \\
\hline
\end{tabular}


Table 3. Linguistic profiles

\begin{tabular}{|c|c|c|}
\hline Demographic Characteristic & $\#$ & $\%$ \\
\hline \multicolumn{3}{|c|}{ Age of First Exposure to American Sign Language } \\
\hline Birth to Age 2 & 8 & $25 \%$ \\
\hline Age 3 to Age 4 & 3 & $9 \%$ \\
\hline Age 5 to Age 6 & 0 & $0 \%$ \\
\hline Age 7 to Age 11 & 7 & $22 \%$ \\
\hline Age $12+$ & 8 & $25 \%$ \\
\hline \multicolumn{3}{|l|}{ Years of American Sign Language Use } \\
\hline 4 to 7 & 2 & $6 \%$ \\
\hline 8 to 9 & 2 & $6 \%$ \\
\hline $10-18$ & 7 & $22 \%$ \\
\hline $19+$ & 21 & $66 \%$ \\
\hline \multicolumn{3}{|l|}{ Age of First Exposure to English } \\
\hline Birth to Age 2 & 17 & $53 \%$ \\
\hline Age 3 to Age 4 & 10 & $31 \%$ \\
\hline Age 5 to Age 6 & 2 & $6 \%$ \\
\hline Age 7 to Age 11 & 2 & $6 \%$ \\
\hline Age $12+$ & 1 & $3 \%$ \\
\hline \multicolumn{3}{|l|}{ Years of English Use } \\
\hline $19+$ & 32 & $100 \%$ \\
\hline \multicolumn{3}{|l|}{ Languages Currently Used } \\
\hline American Sign Language & 32 & $100 \%$ \\
\hline English & 32 & $100 \%$ \\
\hline Spanish & 3 & $9 \%$ \\
\hline Other Spoken & 2 & $6 \%$ \\
\hline Other Signed & 2 & $6 \%$ \\
\hline \multicolumn{3}{|l|}{ Sign Systems Used Throughout Lifetime } \\
\hline American Sign Language & 32 & $100 \%$ \\
\hline PSE/Contact Signs & 22 & $69 \%$ \\
\hline Signed English & 7 & $22 \%$ \\
\hline Cued Speech & 1 & $3 \%$ \\
\hline \multicolumn{3}{|l|}{ Use of Spoken Language } \\
\hline Reading & 32 & $100 \%$ \\
\hline Writing & 32 & $100 \%$ \\
\hline Listening & 13 & $41 \%$ \\
\hline Speaking & 22 & $69 \%$ \\
\hline Lipreading & 25 & $78 \%$ \\
\hline Access via Interpreter & 27 & $84 \%$ \\
\hline \multicolumn{3}{|l|}{ Use of Assistive Listening Devices } \\
\hline Cochlear Implant & 3 & $9 \%$ \\
\hline Hearing Aid(s) & 15 & $47 \%$ \\
\hline None & 14 & $44 \%$ \\
\hline
\end{tabular}




\begin{tabular}{cll}
\hline Motivation for Learning ASL & & \\
1- Not Motivated & 1 & $3 \%$ \\
2- Somewhat Motivated & 0 & $0 \%$ \\
3- Motivated & 3 & $9 \%$ \\
4- Very Motivated & 27 & $84 \%$ \\
5- Not Applicable & 1 & $3 \%$ \\
Motivation for Learning English & & \\
1- Not Motivated & 4 & $13 \%$ \\
2- Somewhat Motivated & 11 & $34 \%$ \\
3- Motivated & 16 & $50 \%$ \\
4- Very Motivated & 1 & $3 \%$ \\
\hline
\end{tabular}

Table 4. Communicative preferences

\begin{tabular}{|c|c|c|}
\hline Demographic Characteristic & $\#$ & $\%$ \\
\hline \multicolumn{3}{|c|}{ Communicative Preferences in Social Settings } \\
\hline \multicolumn{3}{|l|}{ Speaking } \\
\hline 1- Rarely & 8 & $25 \%$ \\
\hline 2- Sometimes & 6 & $19 \%$ \\
\hline 3- Frequently & 8 & $25 \%$ \\
\hline 4- Preferred & 9 & $28 \%$ \\
\hline No Response & 1 & $3 \%$ \\
\hline \multicolumn{3}{|l|}{ Listening } \\
\hline 1- Rarely & 12 & $38 \%$ \\
\hline 2- Sometimes & 7 & $22 \%$ \\
\hline 3- Frequently & 5 & $16 \%$ \\
\hline 4- Preferred & 6 & $19 \%$ \\
\hline No Response & 2 & $6 \%$ \\
\hline \multicolumn{3}{|l|}{ Lipreading } \\
\hline 1- Rarely & 4 & $13 \%$ \\
\hline 2- Sometimes & 8 & $25 \%$ \\
\hline 3- Frequently & 15 & $47 \%$ \\
\hline 4- Preferred & 4 & $13 \%$ \\
\hline \multicolumn{3}{|l|}{ Use of Interpreter } \\
\hline 1- Rarely & 12 & $38 \%$ \\
\hline 2- Sometimes & 7 & $22 \%$ \\
\hline 3- Frequently & 7 & $22 \%$ \\
\hline 4- Preferred & 6 & $19 \%$ \\
\hline \multicolumn{3}{|l|}{ Reading/Writing Notes } \\
\hline 1- Rarely & 6 & $19 \%$ \\
\hline 2- Sometimes & 10 & $31 \%$ \\
\hline 3- Frequently & 12 & $38 \%$ \\
\hline 4- Preferred & 3 & $9 \%$ \\
\hline No Response & 1 & $3 \%$ \\
\hline
\end{tabular}


Table 5. Communicative preferences in academic settings

\begin{tabular}{|c|c|c|}
\hline Demographic Characteristic & $\#$ & $\%$ \\
\hline \multicolumn{3}{|c|}{ Communicative Preferences in Academic Settings } \\
\hline \multicolumn{3}{|l|}{ Speaking } \\
\hline 1- Rarely & 8 & $25 \%$ \\
\hline 2- Sometimes & 10 & $31 \%$ \\
\hline 3- Frequently & 3 & $9 \%$ \\
\hline 4- Preferred & 8 & $25 \%$ \\
\hline No Response & 3 & $9 \%$ \\
\hline \multicolumn{3}{|l|}{ Listening } \\
\hline 1- Rarely & 15 & $47 \%$ \\
\hline 2- Sometimes & 6 & $19 \%$ \\
\hline 3- Frequently & 5 & $16 \%$ \\
\hline 4- Preferred & 4 & $13 \%$ \\
\hline No Response & 2 & $6 \%$ \\
\hline \multicolumn{3}{|l|}{ Lipreading } \\
\hline 1- Rarely & 9 & $28 \%$ \\
\hline 2- Sometimes & 7 & $22 \%$ \\
\hline 3- Frequently & 10 & $31 \%$ \\
\hline 4- Preferred & 4 & $13 \%$ \\
\hline No Response & 2 & $6 \%$ \\
\hline \multicolumn{3}{|l|}{ Use of Interpreter } \\
\hline 1- Rarely & 3 & $9 \%$ \\
\hline 2- Sometimes & 5 & $16 \%$ \\
\hline 3- Frequently & 6 & $19 \%$ \\
\hline 4- Preferred & 18 & $56 \%$ \\
\hline \multicolumn{3}{|l|}{ Reading/Writing Notes } \\
\hline 1- Rarely & 2 & $6 \%$ \\
\hline 2- Sometimes & 6 & $19 \%$ \\
\hline 3- Frequently & 14 & $44 \%$ \\
\hline 4- Preferred & 8 & $25 \%$ \\
\hline No Response & 2 & $6 \%$ \\
\hline
\end{tabular}

\subsection{Instrumentation}

Relational constructs were quantified and measured with a variety of instruments. The Stanford Achievement Test, $10^{\text {th }}$ Edition (Stanford 10) was used to quantify Reading Comprehension, Reading Vocabulary, Language, Mathematics, and Science skills. The highest test level, the TASC 3, was administered.

\subsubsection{American Sign Language Skills}

The Test of American Sign Language-Receptive (TASLA-R), developed by Smith (2007) was used to evaluate ASL skills. This 40 item test measures ASL receptive skills related to phonology, morphology, semantics, syntax, and pragmatics. This instrument was chosen for its validity, reliability, and usability. A panel of ASL linguists, ASL/English bilingual educators, teachers of ASL as a second language, and a psychologist approved the final test revisions to ensure construct validity. The Kuder-Richardson 21 Coefficient of Internal Consistency Analysis showed a moderate degree of internal consistency (.74). Predictive validity was determined by comparing the 
TASLA-R to the Bellugi ASL test- an analyses that yielded a statistically significant relationship according to the Pearson product moment correlation coefficient $(r=.540 ; p=.01)$. The test was also teacher-friendly and can be given via a computer program or by video. The TASLA-R yielded raw scores that were converted to $z$-scores for statistical analyses.

\subsubsection{Metacognition}

Metacognition was quantified by the Metacognitive Awareness of Reading Skill Inventory (MARSI), developed by Mokhtari and Reichard (2002). The MARSI is designed to assess adolescent and adult readers' metacognitive awareness and perceived use of reading strategies while reading academic or school-related materials (Mokhtari \& Reichard, 2002). This 30 item inventory asks individuals to report their perceptions of their own metacognition by answering questions related to whether or not they use specific strategies. Test items were constructed based on a review of current literature on metacognition and standard development measures, including successive cycles of development, field testing, validation, and revision. Reliability analyses were conducted using factor correlations and calculations of Cronbach's alpha for pilot studies separating students from 6-12 grades. Results yielded strong reliability $(\alpha=.86-.93)$. The MARSI reported an overall score and differentiated between skills in global reading strategies, problem-solving strategies, and support reading strategies. The scoring rubric helped researchers assign a rating of high, medium, or low skill for each subset and the overall instrument. Raw scores were converted to z-scores for statistical analyses.

\subsubsection{Metalinguistic Awareness}

The Metalinguistic Awareness of Translation Strategy Inventory for English to ASL Tasks (MATSI), was designed by the principal investigator to assess adult bilinguals' metalinguistic awareness of perceived strategy usage while completing English-to-ASL translation tasks. As with metacognition, no instrument can completely measure metalinguistic awareness. This 41-item inventory asked individuals to report their perceptions of their metalinguistic awareness by answering questions related to whether or not they used specific strategies. Reliability analyses were conducted using a calculation of Cronbach's alpha $(\alpha=.94)$. The MATSI: English-to-ASL yielded raw scores that were converted to z-scores for statistical analyses.

\subsubsection{Reading Translation}

The Reading Translation (English to ASL) Instrument (RTEA-I) was developed by the investigator to evaluate English to ASL translation skill as exhibited on signed renditions of English texts captured via electronic media. A set of English source texts were selected by the principal investigator and randomly assigned to participants for translation. Scale items allowed individuals to be rated on their integration of 34 translation elements, including features of ASL and English into their respective translations. For each linguistic feature listed, the rater assigned a value of 0 (not observed), 1 (attempted), 2 (marginal/inconsistent), 3 (appropriate use), or NA (not applicable to the source text). The mean score of all ratings ( 3 samples x 3 raters) yielded a raw score for each participant. Raw scores were converted to z-scores for statistical analyses. This scale was validated by a panel review of eight deaf preservice and inservice teachers. All teachers were bilingual users of ASL and English, five collegiate faculty, six certified interpreters, and five teachers from an ASL/English bilingual program. Reliability analysis of the scale was conducted using a calculation of Cronbach's alpha $(\alpha=.99)$. Three raters were used to rate each participant. Rater \#1 had seven years experience teaching deaf children in a bilingual setting, three years experience as a teacher-trainer, and held a BS and MS in Deaf Education. Rater \#2 had nine years experience teaching deaf children in a bilingual setting and held a MS in Deaf Education. Rater \#3 had twenty-three years experience teaching deaf children, nine years experience as a teacher-trainer, and held a doctorate in Deaf Education. Inter-rater reliability was determined by analysis of intraclass correlation coefficients (ICCs) by a two-way ANOVA mixed effects model with absolute agreement measures. The ICC for single measures was .68 and .99 for average measures.

\section{Results}

\subsection{Descriptive Statistics}

For all test measures, raw scores were calculated based on the total number of correct responses on each test instrument. The administration guide for the Stanford 10 provided standard scores, which were used to guide statistical analysis. For all other measures, raw scores were converted to z-scores prior to analysis. Descriptive statistics for all test measures are shown in Table 6. This included population, mean, and standard deviations for the MARSI and all three subsections, the MATSI, the RTI, TASLA-R with all five subsections, and the reading vocabulary, reading comprehension, language, science and math subtests of the Stanford 10. 
Table 6. Test measures: population, mean, and standard deviation

\begin{tabular}{llll}
\hline TEST MEASURE & N & Mean & SD \\
\hline MARSI Total & 32 & 111.63 & 17.57 \\
MARSI: Global Strategies & 32 & 48.41 & 6.48 \\
MARSI: Problem Solving Strategies & 32 & 33.53 & 10.66 \\
MARSI: Support Strategies & 32 & 29.44 & 6.75 \\
MATSI & 31 & 139.74 & 23.19 \\
RTI & 28 & 73.82 & 26.86 \\
TASLA-R Total & 30 & 31.77 & 4.62 \\
TASLA-R Phonology & 30 & 5.30 & 1.91 \\
TASLA-R Morphology & 30 & 6.73 & 1.01 \\
TASLA-R Semantics & 30 & 7.20 & .85 \\
TASLA-R Syntax & 30 & 5.97 & 1.16 \\
TASLA-R Pragmatics & 30 & 6.57 & 1.17 \\
Stanford 10 Reading Vocabulary & 32 & 743.50 & 47.21 \\
Stanford 10 Reading Comprehension & 32 & 722.56 & 35.18 \\
Stanford 10 English Language & 31 & 716.87 & 38.15 \\
Stanford 10 Mathematics & 30 & 710.13 & 20.65 \\
Stanford 10 Science & 30 & 702.50 & 26.70 \\
\hline
\end{tabular}

\subsection{Correlational Analysis-Instructional Predictors}

The first analysis investigated relationships between instructional predictors. The strength and direction of relationships were measured by the Pearson product moment of correlation coefficients since all variables were quantified with continuous data. A correlational matrix was generated that included all of the above variables. See Table 7. The second analysis investigated the relationship between environmental predictors and reading comprehension. See Tables 8 and 9. The strength and direction of relationships was measured by coefficients of correlation, appropriate to the type of data presented. Pearson $r$ was used to examine continuous variables and the phi coefficient $(\Phi)$ was used to analyze nominal data arranged in dichotomous pairs. Results revealed ten statistically significant relationships between constructs:

$>$ Metalinguistic Awareness and Metacognition.

$>$ Metalinguistic Awareness and ASL Skill.

$>$ English to ASL Translation Ability and ASL Skill.

$>$ English Reading Vocabulary and ASL Skill.

> English Reading Comprehension and ASL Skill.

$>$ English Language and ASL Skill.

$>$ English Reading Vocabulary and Reading Comprehension.

$>$ English Reading Vocabulary and English Language.

$>$ Academic Knowledge (Science) and Language.

$>$ English Language and Reading Comprehension.

The second correlational analysis evaluated the relationship between Reading Comprehension and the remaining categorical environmental variables. Data was arranged in $2 \times 2$ dichotomous pairs, with Reading Comprehension being divided into two groups. Group 1 was comprised of participants whose Reading Comprehension scores was greater than the mean score for the group $(X=722.56)$. Group 2 consisted of participants whose score fell below the mean. See Table $2 \& 4$. Results of this analysis did not show any statistically significant correlations when the phi coefficient of correlation $(\Phi)$ was evaluated. This analysis revealed five statistically significant relationships between environmental variables and reading comprehension. 
These relationships were:

Age of Onset of Deafness and Reading Comprehension.

$>$ Age of Onset of Deafness and Age of First Exposure to English.

$>$ Years of English Use and Years of ASL Use.

$>$ Years of ASL Use and Age of First Exposure to ASL.

$>$ Reading Comprehension and Age of First Exposure to English.

Table 7. Correlational matrix for instructional predictors

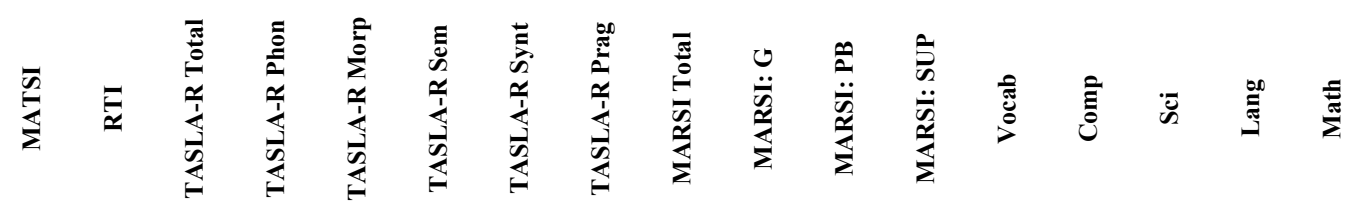

\begin{tabular}{|c|c|c|c|c|c|c|c|c|c|c|c|c|c|c|c|c|c|c|}
\hline \multirow[t]{3}{*}{ MATSI } & $\mathbf{r}$ & 1 & .18 & $.42 *$ & $.37^{*}$ & .37 & $.38^{*}$ & $.42 *$ & .02 & $.62^{* *}$ & $.36^{*}$ & $.54 * *$ & $.41^{*}$ & .17 & .07 & .27 & .10 & .16 \\
\hline & $\mathbf{p}$ & & .37 & .03 & .05 & .05 & .04 & .02 & .94 & .00 & .05 & .00 & .02 & .37 & .70 & .14 & .60 & .42 \\
\hline & $\mathbf{n}$ & 31 & 28 & 29 & 29 & 29 & 29 & 29 & 29 & 31 & 31 & 31 & 31 & 31 & 31 & 31 & 30 & 29 \\
\hline \multirow[t]{3}{*}{ Translation } & $\mathbf{r}$ & .18 & 1 & $.49^{* *}$ & $.39 *$ & $.55^{* *}$ & $.57^{* *}$ & .05 & $.38^{*}$ & .20 & .32 & .19 & -.12 & .14 & .23 & .02 & .35 & .07 \\
\hline & $\mathbf{p}$ & .37 & & .01 & .04 & .00 & .00 & .81 & .05 & .30 & .10 & .34 & .54 & .47 & .25 & .92 & .07 & .74 \\
\hline & $\mathbf{n}$ & 28 & 28 & 28 & 28 & 28 & 28 & 28 & 28 & 28 & 28 & 28 & 28 & 28 & 28 & 28 & 27 & 26 \\
\hline \multirow{3}{*}{$\begin{array}{l}\text { TASLA-R } \\
\text { Total }\end{array}$} & $\mathbf{r}$ & $.42^{*}$ & $.49^{* *}$ & 1 & $.88^{* *}$ & $.79 * *$ & $.67^{* *}$ & $.70^{* *}$ & $.65^{* *}$ & .16 & .07 & .31 & -.20 & .23 & .34 & .25 & .34 & .09 \\
\hline & $\mathbf{p}$ & .03 & .01 & & .00 & .00 & .00 & .00 & .00 & .41 & .71 & .10 & .28 & .23 & .07 & .19 & .07 & .66 \\
\hline & $\mathbf{n}$ & 29 & 28 & 30 & 30 & 30 & 30 & 30 & 30 & 30 & 30 & 30 & 30 & 30 & 30 & 30 & 29 & 28 \\
\hline \multirow{3}{*}{$\begin{array}{l}\text { TASLA-R } \\
\text { Phonology }\end{array}$} & $\mathbf{r}$ & $.37^{*}$ & $.39^{*}$ & $.89^{* *}$ & 1 & $.63^{* *}$ & $.49^{* *}$ & $.60^{* *}$ & .35 & .09 & -.02 & .31 & -.30 & .20 & .28 & .27 & .25 & .12 \\
\hline & $\mathbf{p}$ & .05 & .04 & .00 & & .00 & .01 & .00 & .06 & .65 & .92 & .09 & .11 & .30 & .13 & .15 & .19 & .53 \\
\hline & $\mathbf{n}$ & 29 & 28 & 30 & 30 & 30 & 30 & 30 & 30 & 30 & 30 & 30 & 30 & 30 & 30 & 30 & 29 & 28 \\
\hline \multirow{3}{*}{$\begin{array}{l}\text { TASLA-R } \\
\text { Morph }\end{array}$} & $\mathbf{r}$ & .37 & $.55^{* *}$ & $.79^{* *}$ & $.63^{* *}$ & 1 & $.51^{* *}$ & $.40^{*}$ & $.45^{*}$ & .17 & .13 & .30 & -.21 & $.37^{*}$ & $.39^{*}$ & .01 & .33 & -.00 \\
\hline & $\mathbf{p}$ & .05 & .00 & .00 & .00 & & .00 & .03 & .01 & .37 & .50 & .11 & .27 & .04 & .03 & .95 & .08 & 1.0 \\
\hline & $\mathbf{n}$ & 29 & 28 & 30 & 30 & 30 & 30 & 30 & 30 & 30 & 30 & 30 & 30 & 30 & 30 & 30 & 29 & 28 \\
\hline \multirow{3}{*}{$\begin{array}{l}\text { TASLA-R } \\
\text { Semantics }\end{array}$} & $\mathbf{r}$ & $.38^{*}$ & $.57^{* *}$ & $.67^{* *}$ & $.50^{* *}$ & $.51^{* *}$ & 1 & .25 & $.44 *$ & .27 & .22 & .32 & -.07 & .19 & .17 & .28 & $.45^{*}$ & .23 \\
\hline & $\mathbf{p}$ & .04 & .00 & .00 & .01 & .00 & & .18 & .02 & .15 & .25 & .08 & .72 & .32 & .37 & .13 & .02 & .24 \\
\hline & $\mathbf{n}$ & 29 & 28 & 30 & 30 & 30 & 30 & 30 & 30 & 30 & 30 & 30 & 30 & 30 & 30 & 30 & 29 & 28 \\
\hline \multirow{3}{*}{$\begin{array}{l}\text { TASLA-R } \\
\text { Syntax }\end{array}$} & $\mathbf{r}$ & $.42^{*}$ & .05 & $.70^{* *}$ & $.60^{* *}$ & $.40^{*}$ & .25 & 1 & .27 & .22 & .03 & .25 & .16 & .14 & .17 & .15 & .01 & -.01 \\
\hline & $\mathbf{p}$ & .02 & .81 & .00 & .00 & .03 & .18 & & .15 & .24 & .87 & .19 & .41 & .46 & .36 & .43 & 1.0 & .95 \\
\hline & $\mathbf{n}$ & 29 & 28 & 30 & 30 & 30 & 30 & 30 & 30 & 30 & 30 & 30 & 30 & 30 & 30 & 30 & 29 & 28 \\
\hline \multirow{3}{*}{$\begin{array}{l}\text { TASLA-R } \\
\text { Pragmatics }\end{array}$} & $\mathbf{r}$ & .02 & $.38^{*}$ & $.65^{* *}$ & .35 & $.45^{*}$ & $.44^{*}$ & .27 & 1 & -.08 & .01 & -.02 & -.24 & -.03 & .23 & .16 & .30 & -.01 \\
\hline & $\mathbf{p}$ & .94 & .05 & .00 & .06 & .01 & .02 & .15 & & .66 & .95 & .90 & .20 & .89 & .21 & .40 & .12 & .96 \\
\hline & $\mathbf{n}$ & 29 & 28 & 30 & 30 & 30 & 30 & 30 & 30 & 30 & 30 & 30 & 30 & 30 & 30 & 30 & 29 & 28 \\
\hline \multirow{2}{*}{$\begin{array}{l}\text { MARSI } \\
\text { Total }\end{array}$} & $\mathbf{r}$ & $.62^{* *}$ & .20 & .16 & .09 & .17 & .27 & .22 & -.08 & 1 & $.76^{* *}$ & $.83^{* *}$ & $.57^{* *}$ & .15 & .21 & .12 & .10 & .00 \\
\hline & $\mathbf{p}$ & .00 & .30 & .41 & .65 & .37 & .15 & .24 & .66 & & .00 & .00 & .00 & .41 & .25 & .51 & .61 & 1.0 \\
\hline
\end{tabular}




\begin{tabular}{|c|c|c|c|c|c|c|c|c|c|c|c|c|c|c|c|c|c|c|}
\hline & $\mathbf{n}$ & 31 & 28 & 30 & 30 & 30 & 30 & 30 & 30 & 32 & 32 & 32 & 32 & 32 & 32 & 32 & 31 & 30 \\
\hline \multirow{3}{*}{$\begin{array}{l}\text { MARSI: } \\
\text { Global }\end{array}$} & $\mathbf{r}$ & $.36^{*}$ & .32 & .07 & -.02 & .13 & .22 & .03 & .01 & $.76^{* *}$ & 1 & $.48^{* *}$ & .29 & .28 & .21 & -.00 & .14 & .11 \\
\hline & $\mathbf{p}$ & .05 & .10 & .71 & .92 & .50 & .25 & .87 & .95 & .00 & & .01 & .11 & .13 & .26 & .99 & .40 & .58 \\
\hline & $\mathbf{n}$ & 31 & 28 & 30 & 30 & 30 & 30 & 30 & 30 & 32 & 32 & 32 & 32 & 32 & 32 & 32 & 31 & 30 \\
\hline \multirow{3}{*}{$\begin{array}{l}\text { MARSI: } \\
\text { Problem } \\
\text {-Solving }\end{array}$} & $\mathbf{r}$ & $.54^{* *}$ & .19 & .31 & .31 & .30 & .32 & .25 & -.02 & $.83^{* * *}$ & $.48^{* *}$ & 1 & .14 & .16 & .34 & .23 & .16 & .02 \\
\hline & $\mathbf{p}$ & .00 & .34 & .10 & .09 & .11 & .08 & .19 & .90 & .00 & .01 & & .46 & .40 & .06 & .20 & .38 & .93 \\
\hline & $\mathbf{n}$ & 31 & 28 & 30 & 30 & 30 & 30 & 30 & 30 & 32 & 32 & 32 & 32 & 32 & 32 & 32 & 31 & 30 \\
\hline \multirow{3}{*}{$\begin{array}{l}\text { MARSI: } \\
\text { Support }\end{array}$} & $\mathbf{r}$ & $.41^{*}$ & -.12 & -.20 & -.30 & -.21 & -.07 & .16 & -.24 & $.57 * *$ & .29 & .14 & 1 & -.13 & -.23 & -.08 & -19 & -.15 \\
\hline & $\mathbf{p}$ & .02 & .54 & .28 & .11 & .27 & .72 & .41 & .20 & .00 & .11 & .46 & & .46 & .21 & .67 & .31 & .45 \\
\hline & $\mathbf{n}$ & 31 & 28 & 30 & 30 & 30 & 30 & 30 & 30 & 32 & 32 & 32 & 32 & 32 & 32 & 32 & 31 & 30 \\
\hline \multirow{3}{*}{$\begin{array}{l}\text { Stanford } 10 \\
\text { Reading } \\
\text { Vocab }\end{array}$} & $\mathbf{r}$ & .17 & .14 & .23 & .20 & $.37^{*}$ & .19 & .14 & -.03 & .15 & .28 & .16 & -.13 & 1 & $.68^{* *}$ & .24 & $.68^{* *}$ & .09 \\
\hline & $\mathbf{p}$ & .37 & .47 & .23 & .30 & .05 & .32 & .46 & .89 & .41 & .13 & .40 & .46 & & .00 & .18 & .00 & .63 \\
\hline & $\mathbf{n}$ & 31 & 28 & 30 & 30 & 30 & 30 & 30 & 30 & 32 & 32 & 32 & 32 & 32 & 32 & 32 & 31 & 30 \\
\hline \multirow{3}{*}{$\begin{array}{l}\text { Stanford } \\
\text { Reading } \\
\text { Comp }\end{array}$} & $\mathbf{r}$ & .07 & .23 & .34 & .28 & $.40^{*}$ & .17 & .17 & .23 & .21 & .21 & .34 & -.23 & $.68^{* *}$ & 1 & .22 & $.72 * *$ & .12 \\
\hline & $\mathbf{p}$ & .70 & .25 & .07 & .13 & .03 & .37 & .36 & .21 & .25 & .26 & .06 & .21 & .00 & & .22 & .00 & .55 \\
\hline & $\mathbf{n}$ & 31 & 28 & 30 & 30 & 30 & 30 & 30 & 30 & 32 & 32 & 32 & 32 & 32 & 32 & 32 & 31 & 30 \\
\hline \multirow{3}{*}{$\begin{array}{l}\text { Stanford } \\
\text { Science }\end{array}$} & $\mathbf{r}$ & .27 & .02 & .25 & .27 & .01 & .28 & .15 & .16 & .12 & -.00 & .23 & -.08 & .24 & .22 & 1 & $.45^{*}$ & .22 \\
\hline & $\mathbf{p}$ & .14 & .92 & .19 & .15 & .95 & .13 & .43 & .40 & .51 & .99 & .20 & .67 & .18 & .22 & & .01 & .25 \\
\hline & $\mathbf{n}$ & 31 & 28 & 30 & 30 & 30 & 30 & 30 & 30 & 32 & 32 & 32 & 32 & 32 & 32 & 32 & 31 & 30 \\
\hline \multirow{3}{*}{$\begin{array}{l}\text { Stanford } 10 \\
\text { Language }\end{array}$} & $\mathbf{r}$ & .10 & .35 & .34 & .25 & .33 & $.45^{*}$ & .01 & .30 & .10 & .14 & .16 & -.19 & $.68^{* *}$ & $.72^{* *}$ & $.45^{*}$ & 1 & .32 \\
\hline & $\mathbf{p}$ & .60 & .07 & .07 & .19 & .08 & .02 & .97 & .12 & .61 & .46 & .38 & .31 & .00 & .00 & .01 & & .09 \\
\hline & $\mathbf{n}$ & 30 & 27 & 29 & 29 & 29 & 29 & 29 & 29 & 31 & 31 & 31 & 31 & 31 & 31 & 31 & 31 & 29 \\
\hline \multirow{3}{*}{$\begin{array}{l}\text { Stanford } 10 \\
\text { Math }\end{array}$} & $\mathbf{r}$ & .16 & .07 & .09 & .12 & -.00 & .23 & -.01 & -.01 & .00 & .11 & .02 & -.15 & .09 & .12 & .22 & .32 & 1 \\
\hline & $\mathbf{p}$ & .42 & .74 & .66 & .53 & 1.0 & .24 & .95 & .96 & 1.0 & .58 & .93 & .45 & .63 & .55 & .25 & .09 & \\
\hline & $\mathbf{n}$ & 29 & 26 & 28 & 28 & 28 & 28 & 28 & 28 & 30 & 30 & 30 & 30 & 30 & 30 & 30 & 29 & 30 \\
\hline
\end{tabular}

*Correlations significant at the .05 level. ${ }^{* *}$ Correlations significant at the .01 level. 
Table 8. Correlational matrix for scaled environmental variables

\begin{tabular}{|c|c|c|c|c|c|c|c|}
\hline & & Read Comp & $\begin{array}{l}\text { Age of } \\
\text { Onset }\end{array}$ & $\begin{array}{c}\text { Years of } \\
\text { Eng }\end{array}$ & $\begin{array}{l}\text { Age of Exp } \\
\text { to Eng }\end{array}$ & $\begin{array}{c}\text { Years of } \\
\text { ASL }\end{array}$ & $\begin{array}{l}\text { Age of Exp } \\
\text { to ASL }\end{array}$ \\
\hline \multirow{3}{*}{$\begin{array}{l}\text { Read } \\
\text { Comp }\end{array}$} & $\mathbf{r}$ & 1 & $.552 * *$ & -.008 & $-.650 * *$ & -.111 & -.133 \\
\hline & Sig & & .001 & .966 & .000 & .544 & .469 \\
\hline & $\mathbf{n}$ & 32 & 32 & 32 & 32 & 32 & 32 \\
\hline \multirow{3}{*}{$\begin{array}{l}\text { Age of } \\
\text { Onset }\end{array}$} & $\mathbf{r}$ & $.552 * *$ & 1 & .035 & $-.428 *$ & -.318 & .204 \\
\hline & Sig & .001 & & .848 & .015 & .076 & .263 \\
\hline & $\mathbf{n}$ & 32 & 32 & 32 & 32 & 32 & 32 \\
\hline \multirow{3}{*}{$\begin{array}{l}\text { Years of } \\
\text { Eng }\end{array}$} & $\mathbf{r}$ & -.008 & .035 & 1 & .110 & $.715^{* *}$ & -.303 \\
\hline & Sig & .966 & .848 & & .547 & .000 & .091 \\
\hline & $\mathbf{n}$ & 32 & 32 & 32 & 32 & 32 & 32 \\
\hline \multirow{3}{*}{$\begin{array}{l}\text { Age of } \\
\text { Exp to } \\
\text { Eng }\end{array}$} & $\mathbf{r}$ & $-.650 * *$ & $-.428^{*}$ & .110 & 1 & .300 & -.011 \\
\hline & Sig & .000 & .015 & .547 & & .096 & .951 \\
\hline & $\mathbf{n}$ & 32 & 32 & 32 & 32 & 32 & 32 \\
\hline \multirow{3}{*}{$\begin{array}{l}\text { Years of } \\
\text { ASL }\end{array}$} & $\mathbf{r}$ & -.111 & -.318 & $.715^{* *}$ & .300 & 1 & $-.764 * *$ \\
\hline & Sig & .544 & .076 & .000 & .096 & & .000 \\
\hline & $\mathrm{n}$ & 32 & 32 & 32 & 32 & 32 & 32 \\
\hline \multirow{3}{*}{$\begin{array}{l}\text { Age of } \\
\text { Exp to } \\
\text { ASL }\end{array}$} & $\mathbf{r}$ & -.133 & .204 & -.303 & -.011 & $-.764 * *$ & 1 \\
\hline & Sig & .469 & .263 & .091 & .951 & .000 & \\
\hline & $\mathrm{n}$ & 32 & 32 & 32 & 32 & 32 & 32 \\
\hline
\end{tabular}

** Correlation is significant at the 0.01 level (2-tailed). ${ }^{*}$ Correlation is significant at the 0.05 level (2-tailed).

Table 9. Arrangement of dichotomous pairs for nominal data

\begin{tabular}{|c|c|c|c|c|}
\hline \multirow{2}{*}{\multicolumn{2}{|c|}{ Variable Groups }} & \multicolumn{2}{|c|}{ Read Comp Group } & \multirow[b]{2}{*}{ n } \\
\hline & & Below & Above & \\
\hline \multirow{2}{*}{ Etiology of Deafness } & Genetic & 2 & 3 & 5 \\
\hline & Non-Genetic & 14 & 13 & 27 \\
\hline \multirow{2}{*}{ Degree of Hear Loss } & $\mathrm{Mod} / \mathrm{Sev}$ & 3 & 1 & 4 \\
\hline & Profound & 13 & 15 & 28 \\
\hline \multirow{2}{*}{ Ethnicity } & Non-Diverse & 10 & 13 & 23 \\
\hline & Diverse & 6 & 3 & 9 \\
\hline \multirow{2}{*}{ Parental Hear Status } & Deaf & 2 & 5 & 7 \\
\hline & Hearing & 14 & 11 & 25 \\
\hline \multirow{2}{*}{ Sibling Hear Status } & Deaf & 4 & 5 & 9 \\
\hline & Hearing & 12 & 11 & 23 \\
\hline \multirow{2}{*}{ Familial Hear Status } & Deaf & 5 & 4 & 9 \\
\hline & Hearing & 11 & 12 & 23 \\
\hline
\end{tabular}




\subsection{Multiple Regression Analysis}

A stepwise selection method allowed researchers to identify a list of potential independent variables. SPSS was then used to choose among them based on statistical criteria to create prediction models. Three different regressions were conducted. The first considered all continuous data. The second considered only the prediction model from Figure 1. The third analysis presented a reduced model that more accurately depicted language interdependence.

\subsubsection{Multiple Regression \#1: Continuous Data}

All continuous data was used for this analysis. This included: 1) age of onset of deafness, 2) years of English use; 3) years of ASL use; 4) age of exposure to English; 5) age of exposure to ASL; 6)MATSI; 7) RTI; 8)TASLA-R Total Scale; 9) TASLA-R Phonology; 10) TASLA-R Morphology; 11) TASLA-R Syntax; 12)TASLA-R Semantics; 12) TASLA-R Pragmatics; 13) MARSI Total Scale; 14) MARSI Global Strategies; 15) MARSI Problem Solving Strategies; 16) MARSI Support Strategies; 17) Stanford 10 Science; 18) Stanford 10 Math; 19) Stanford 10 Vocabulary; and 20) Stanford 10 Language. All twenty variables were included as independent variables. SPSS generated three statistically significant models that could be used to predict the distribution of Reading Comprehension scores.

- Model 1 Predictors: Age of First Exposure to English $(\mathrm{R}=.70, \mathrm{R}$ square $=.49$, adjusted $\mathrm{R}$ square $=.47, \mathrm{~F}=$ $21.87, p=.00)$.

- Model 2 Predictors: Age of First Exposure to English, Stanford 10 Reading Vocabulary $(\mathrm{R}=.81$, $\mathrm{R}$ square $=.67$, adjusted $\mathrm{R}$ square $=.64, \mathrm{~F}=22.16, \mathrm{p}=.00$ ).

- Model 3 Predictors: Age of First Exposure to English, Stanford 10 Reading Vocabulary, Stanford 10 Language $(\mathrm{R}=.85, \mathrm{R}$ square $=.73$, adjusted $\mathrm{R}$ square $=.69, \mathrm{~F}=18.55, \mathrm{p}=.00)$.

\subsubsection{Multiple Regression \#2: Testing the Prediction Model}

The second regression analysis considered the prediction model presented in Chapter 2, Figure 1. All of the predictor variables were entered into the multiple regression equation. SPSS generated two statistically significant models, the second of which held the most predictive ability.

- Model 4 Predictors: Stanford 10 Language $(\mathrm{R}=.67, \mathrm{R}$ square $=.45$, adjusted $\mathrm{R}$ square $=.43, \mathrm{~F}=18.95, \mathrm{p}$ $=.00)$.

- Model 5 Predictors: Stanford 10 Reading Vocabulary $(\mathrm{R}=.75, \mathrm{R}$ square $=.56$, adjusted $\mathrm{R}$ square $=.51, \mathrm{~F}=$ $13.70, \mathrm{p}=.00)$.

\subsubsection{Multiple Regression \#3: Elimination of English Factors}

The third regression analysis considered a reduced model from the previous two analyses. the third analysis attempted to more clearly understand which variables could best predict reading comprehension skill. A reduced model from regression \#2 was used, which eliminated Reading Vocabulary and Language subtests as independent variables. Unfortunately, SPSS was unable to generate a prediction model. Scaled environmental variables were added back into the equation (without adding English variables) and the analysis was run again. The following were entered as independent variables: 1) age of onset of deafness, 2) years of ASL use; 3) age of exposure to ASL; 4) MATSI; 5) RTI; 6) TASLA-R Total Scale; 7) TASLA-R Phonology; 8) TASLA-R Morphology; 9) TASLA-R Syntax; 10) TASLA-R Semantics; 11) TASLA-R Pragmatics; 12) MARSI Total Scale; 13) MARSI Global Strategies; 14) MARSI Problem Solving Strategies; 15) MARSI Support Strategies; 16) Stanford 10 Science; and 17) Stanford 10 Math. SPSS was then able to generate two statistically significant models.

- $\quad$ Model 6 Predictors: Age of Onset of Deafness $(\mathrm{R}=.39, \mathrm{R}$ square $=.15$, adjusted $\mathrm{R}$ square $=.12, \mathrm{~F}=4.32, p$ $=.05$ ).

- Model 7 Predictors: Age of Onset of Deafness and TASLA-R Morphology Subscale $(\mathrm{R}=.61$, $\mathrm{R}$ square $=.37$, adjusted $\mathrm{R}$ square $=.31, \mathrm{~F}=6.70, p=.01$ ).

The findings in Model 7 were interesting. This data suggested that ASL skill, specifically regarding ASL morphology, might be able to predict Reading Comprehension, when considered alongside age of onset of deafness. Interestingly, a statistically significant relationship was not identified between age of onset of deafness and ASL Morphology when Pearson $r$ was evaluated.

\subsection{Qualitative Analysis}

Participants were required to answer open-ended questions related to language use. One question held valuable 
information relative to the question of language interdependence. Researchers asked, "As a bilingual user of American Sign Language and English, how do you believe that you personally use ASL to help you understand English?" Interestingly, 15 of the 32 respondents specifically referred to the use of ASL to help them visualize the content in English passages and understand important concepts more clearly. Many participants explained that using an ASL translation process helped mediate difficult information, discuss concepts and information, and improved overall comprehension. Those participants who did not note these procedures stated English was their first language and did not need ASL support.

\subsection{Limitations of the Study}

Certain limitations existed within this study. Sample size is seen as a clear limitation and attempts to generalize should be done with caution. Secondly, adults in this study had advanced educational training and therefore may have unique skill. Thirdly, the study is an attempt to understand certain phenomenon occurring within deaf bilinguals so that further study with deaf bilingual children can be conducted. Deaf adults have the ability to discuss complex linguistic issues whereas children may not possess these skills. Results should not be generalized to children. Fourthly, multiple regression analyses are used in this study. Typically, the number of variables is limited to population size. The researcher imposed no restrictions on the number of variables considered. Finally, researcher-developed instruments have not undergone rigorous pilots and results should be interpreted with caution.

\subsection{Delimitations of the Study}

Certain delimitations are imposed upon the study by the investigator. This study was limited to a purposive sampling of ASL/English bilingual deaf adults. Additionally, the study used only static measures of assessment to quantify complex constructs in an effort not to hinder statistical analyses.

\section{Discussion}

Language interdependence between ASL and English was central to the study. Specifically, whether or not Cummins' Language Threshold Theory and Language Interdependence Theory could be applied to ASL/English bilinguals was considered. Discussion of results as related to these two theories follows.

\subsection{Language Threshold Theory}

Cummins' Threshold Hypothesis provided insight into the specific conditions under which language functioned as an intervening variable (Cummins, 1976, 1979, 1981, 2003). He emphasized language experiences and language handling as determining factors for educational and linguistic performance (Cummins, 1976, 1979, 1981, 2003). He postulated that continued academic development of both languages conferred cognitive and linguistic benefits (Cummins, 1976, 1979, 1981, 2003). He stated, "Bilingual students who continue to develop both languages in the school context appear to experience positive cognitive and academic outcomes" (p. 174). Results of this study are supportive of this notion. Participants in the research sample experienced positive academic outcomes, as all were pursuing college degrees, with the majority pursuing professional degrees. Continued academic development of ASL and English could have translated into cognitive and linguistic benefits that supported their educational successes. Clearly, dual language use was an integral part of each participant's daily social and academic environment. The Threshold Hypothesis could be applied to this group of individuals, with ASL acting as the intervening variable.

\subsection{Language Interdependence Theory}

Cummins' (1976, 1979, 1981, 2003) language interdependence theory hypothesized that common linguistic proficiencies underlie all languages and that academic language proficiencies could transfer from one language to the other(s). First language conceptual and background knowledge could be utilized to facilitate the acquisition of second language literacy and subject matter content (Cummins, 1979, 1981). Academic language proficiency could be easily attained in the second language if it sufficiently existed in the first (Cummins, 2003). However, first language proficiencies could only support second language learning if there was adequate exposure to the second language and motivation to learn it (Cummins, 1981). Results in the study are supportive of this theory. Participants reported using ASL background and conceptual knowledge to assist with English literacy tasks. Most participants noted preferences for ASL over English in academic settings, suggesting that conceptual knowledge sufficiently existed in their preferred language. Participants reported adequate exposure to English (excess of 19 years) and sufficient motivation to learn it. Specific proficiencies seemed to be transferring between ASL Morphology and English Reading Vocabulary, ASL Morphology and English Reading Comprehension, and ASL Semantics and English Language Mechanics. 


\subsection{Suggestions for Future Research}

Three interesting findings in this study provided insight into possibilities for further research regarding language interdependence. Statistically significant relationships were identified between Reading Comprehension and ASL Morphology, Reading Vocabulary and ASL Morphology, and English Language Skill and ASL Semantics. Studies that further investigate these constructs are needed. Qualitative studies could be of great value concerning issues raised in this study. The use of Think Aloud Protocols to examine metalinguistic awareness and metacognition could be beneficial. Think Aloud Protocols may also be beneficial in studies that examine the translation process for deaf readers. Case studies or ethnographies that consider English to ASL translations and variations across social and ethnic groups could be valuable. Additional quantitative studies may be necessary as well. Tests that measure expressive ASL skills are needed. Tests that can better measure reading vocabulary and ASL vocabulary need to be developed. Item analysis studies of reading comprehension, reading vocabulary, English language, science, and mathematics tests need to be conducted to determine which skill areas are problematic and Clearly, additional research is needed to more fully understand how deaf bilinguals utilize ASL knowledge to assist with English reading tasks. For instructional practices to improve, evidence-driven decision-making is vital. Without further research, professionals cannot be empowered to impact pedagogy

\section{References}

Andrews, J. F., \& Mason, J. (1991). Strategy usage among deaf and hearing readers. Exceptional Children, 57(6), 536-545.

Andrews, J. F., \& Rusher, M. (2010). Codeswitching techniques: Evidence-based practices for the ASL/English bilingual classroom. A review of four studies supporting the use of codeswitching. American Annals of the Deaf, 155(4).

Andrews, J. F., Ferguson, C., Roberts, S., \& Hodges, P. (1997). What's up Billy Jo? Deaf children and bilingual-bicultural instruction in East-Central Texas. American Annals of the Deaf, 142(1), 16-25. http://dx.doi.org/10.1353/aad.2012.0233

Andrews, J. F., Winograd, P., \& DeVille, G. (1994). Deaf children reading fables: Using ASL summaries to improve reading comprehension. American Annals of the Deaf, 139(3), 378-386. http://dx.doi.org/10.1353/aad.2012.0303

Bailes, C. (2001). Integrative ASL-English language arts: Bridging paths to literacy. Sign Language Studies, 1(2), 147-174. http://dx.doi.org/10.1353/sls.2001.0002

Chamberlain, C., \& Mayberry, R. (2000). Theorizing about the relation between American Sign Language and Reading. In C. Chamberlain, J. Morford, \& R. Mayberry (Eds.), Language acquisition by eye (pp. 221-260). Mahwah, NJ: Lawrence Erlbaum Publishers.

Chamberlain, C., Morford, J., \& Mayberry, R. (2000). Language acquisition by eye. Mahwah, NJ: Lawrence Erlbaum Publishers.

Cummins, J. (1976). The influence of bilingualism on cognitive growth: A synthesis of research findings and explanatory hypotheses. Working Papers on Bilingualism, 9, 1-43. http://dx.doi.org/10.3102/00346543049002222

Cummins, J. (1979). Linguistic interdependence and the educational development of bilingual children. Review of Educational Research, 49, 222-251.

Cummins, J. (1981). The role of primary language development in promoting educational success for language minority students. In California State Department of Education. Schooling and language minority students: A theoretical framework. Los Angeles: Evaluation, Assessment, and Dissemination Center.

Cummins, J. (2000). Language, power, and pedagogy: Bilingual children in the crossfire. Buffalo, NY: Multilingual Matters Ltd.

Cummins, J. (2003). BICS and CALP. University of Toronto. Retrieved March 1, 2004, from http://www.iteachilearn.com/cummins/bicscalp.html

DeLana, M. (2004). The impact of ASL/English bilingual education upon reading comprehension achievement of public school students who are deaf and hard of hearing (Master's thesis). Retrieved from ProQuest Dissertations and Theses (Accession Order No. AAT 1426132.)

DeLana, M., Gentry, M., \& Andrews, J. (2007). The efficacy of ASL/English bilingual education: Investigating public schools. American Annals of the Deaf, 152(1), 73-87. http://dx.doi.org/10.1353/aad.2007.0010 
Geeslin, J. D., III. (2007). Deaf bilingual education: A comparison of the academic Performance of deaf children of deaf parents and deaf children of hearing parents. Paper submitted to the faculty of the School of Education in partial fulfillment of the requirements for the degree Doctor of Education in the Department of Educational Leadership and Policy Studies. Indiana University.

Hansen, L. L., \& Mosqueira, J. A. (1996). ASL to English strategies: A bilingual approach. CAL-Ed Presentation. Fremont, CA: California School for the Deaf.

Haptonstall-Nykaza, T. S., \& Schick, B. (2007). The transition from fingerspelling to English print: Facilitating English decoding. Journal of Deaf Studies and Deaf Education, 12(2), 172-183. http://dx.doi.org/10.1093/deafed/enm003

Hoffmeister, R. J. (2000). A piece of the puzzle: ASL and reading comprehension in deaf children. In C. Chamberlain, J. P. Morford, \& R. Mayberry (Eds.), Language acquisition by eye (pp. 143-163). Mahwah, NJ: Lawrence Erlbaum Publishers.

Hoffmeister, R., Philip, M., Costello, P., \& Grass, W. (1997). Evaluating American Sign Language in deaf children: ASL influences on reading with a focus on classifiers, plurals, verbs of motion and location. In J. Mann (Ed.), Proceedings of Deaf Studies V Conference. Washington, D.C.: Gallaudet University.

Kuntze, M. (2004). Literacy acquisition and deaf children: A study of the interaction between ASL and written English (Unpublished dissertation). Stanford University, Stanford, CA.

Lartz, M., \& Lestina, L. (1995). Strategies deaf mothers use when reading to their young deaf or hard of hearing children. American Annals of the Deaf, 140(4), 358-362. http://dx.doi.org/10.1353/aad.2012.0358

Li, Y. (2005). The effects of the bilingual strategy-preview, view, review-On the comprehension of science concepts by deaf ASL/English and hearing Mexican-American Spanish/English bilingual students (Unpublished dissertation). Lamar University, Beaumont, TX.

Livingston, S. (1997). Rethinking the education of deaf students: Theory and practice from a teacher's perspective. Portsmouth, NH: Heinemann.

Luetke-Stahlman, B. (1990). Types of instructional input as predictors of reading achievement for hearing impaired students. In C. Lucas (Ed.), Sign language research: Theoretical issues. Washington, D.C.: Gallaudet University Press.

Marschark, M., Siple, P., Lillo-Martin, D., Campbell, R., \& Everhart, V. (1997). Relations of language and thought: The view form sign language and deaf children. Oxford, England: Oxford University Press.

Mayberry, R. (1989, April). Deaf children's reading comprehension in relation to sign language structure and input. Paper presented at the Society for Research in Child Development, Kansas City.

Mayberry, R. (1994). The importance of childhood to language acquisition: Evidence from American Sign Language. In J. C. Goodman, \& H. C. Nusbaum (Eds.), The development of speech perception (pp. 60-89). Cambridge, NY: MIT Press.

Mayberry, R., Chamberlain, C., Waters, G., \& Doehring, D. (1999). Reading development in relations to singed language input and structure. Manuscript in preparation.

Mayer, C., \& Akamatsu, C. T. (2003). Bilingualism and literacy. In M. Marschark, \& P. E. Spencer (Eds.), Deaf studies, language, and education (pp. 136-147). New York, NY: Oxford University Press.

Mayer, C., \& Wells, G. (1996). Can the linguistic interdependence theory support a bilingual-bicultural model of literacy education for deaf students? Journal of Deaf Studies and Deaf Education, 1, 93-107. http://dx.doi.org/10.1093/oxfordjournals.deafed.a014290

Mokhtari, K., \& Reichard, C. (2002). Assessing students' metacognitive awarness of reading strategies. Journal of Educational Psychology, 94(2), 249-259. http://dx.doi.org/10.1037/0022-0663.94.2.249

Moores, D. F., \& Sweet, C. A. (1990, June 1). Reading and Writing Skills in Deaf Adolescents. International Journal of Rehabilitation Research, 13.

Moores, D. F., Kluwin, T. N., Johnson, R., Cox, P., Blennerhasset, L., Kelly, ... Fields, L. (1987). Factors predictive of literacy in deaf adolescents (Final Report to National Institute on Nuerological and Communicative Disorders and Stroke Project No. NIH-NINCDS-83-19). Washington, DC: NIH.

Myers, M. R. (2011). The relationship between English reading comprehension and years enrolled at a residential school for the deaf (Unpublished doctoral dissertation). Beaumont, TX: Lamar University. 
Nover, S., \& Andrews, J. (1998). Issue 10: Will ASL storysigning facilitate deaf students' learning to read in English? Critical pedagogy in deaf education: Bilingual methodology and staff development. USDLC Star Schools Project Report No. 1 (pp. 60-65). Santa Fe, NM: New Mexico School for the Deaf.

Nover, S. (2006, February). Language Planning. Paper presented at the Association of College Educators of the Deaf and Hard of Hearing, Denver, Colorado.

Nover, S., Andrews, J., Baker, S., Everhart, V., \& Bradford, M. (2002). Staff development in ASL/English bilingual instruction for deaf students: Evaluation and impact study. USDLC Star Schools project report no. 5. Retrieved May 16, 2005, from http://www.nmsd.k12.nm.us/caeber/documents/year5.pdf

Nover, S., Christensen, K., \& Cheng, L. (1998). Development of ASL and English competence for learners who $\begin{array}{lllll}\text { are deaf. Topics in Language } & \text { Disorders, }\end{array}$ http://dx.doi.org/10.1097/00011363-199818040-00007

Padden, C., \& Hanson, V. (2000). Search for the missing link: The development of skilled reading in deaf children. In Emmorey, \& Lane (Eds.), The signs of language revisited: An anthology to honor Ursulla Bellugi and Edward Klima (pp. 435-447). Mahwah, NJ: Lawrence Erlbaum Associates.

Padden, C., \& Ramsey, C. (1998). Reading ability in signing deaf children. Topics in Language Disorders, 18(4), 30-46. http://dx.doi.org/10.1097/00011363-199818040-00006

Prinz, P., \& Strong, M. (1998). ASL proficiency and English literacy within a bilingual deaf education model of $\begin{array}{lllll}\text { instruction. Topics in } & \text { Language }\end{array}$ http://dx.doi.org/10.1097/00011363-199818040-00006

Prinz, P., \& Strong, M. (2000). Is American Sign Language skill related to English literacy? In C. Chamberlain, J. P. Morford, \& R. Mayberry (Eds.), Language acquisition by eye (pp. 131-141). Mahwah, NJ: Lawrence Erlbaum Publishers.

Rittenhouse, B., Jenkins, M., \& Dancer, J. (2002). Defining the journey: Comparing comprehension in American Sign Language and Signed English storytelling. Odyssey, Winter 2002, 28-29.

Schimmel, C. S., Edwards, S. G., \& Prickett, H. T. (1999). Reading? ... Pah! (I got it!): Innovative reading techniques for successful deaf readers. American Annals of the Deaf, 144(4), 298-308. http://dx.doi.org/10.1353/aad.2012.0342

Schirmer, B. (2001). Constructing meaning from narrative text. American Annals of the Deaf, 138(5), 397-403. http://dx.doi.org/10.1353/aad.2012.0354

Simms, L., Andrews, J. F., \& Smith, A. (2005). A balanced approach to literacy instruction for deaf signing students. Balanced Reading Instruction, 39-53.

Singleton, J. L., Supalla, S., Litchfield, S., \& Schley, S. (1998). From sign to word: Considering modality constraints in ASL/English bilingual education. Topics in Language Disorders, 18(4), 16-29. http://dx.doi.org/10.1097/00011363-199818040-00004

Smith, A. (2007). The performance of deaf students on a Test of American Sign Language Abilities-Receptive (TASLA-R) (Unpublished dissertation). Lamar University, Beaumont, TX.

Wilbur. (2000). The use of ASL to support the development of English and literacy. Journal of Deaf Studies and Deaf Education, 5(1), 81-103.

\section{Note}

Note 1. The term Deaf used throughout this paper denotes individuals who are members of the American Deaf Community, and identified themselves as culturally "Deaf" and who use American Sign Language and English in their daily lives, as opposed to "deaf" which denotes only sensory impairment which would have no relevancy to this study.

\section{Copyrights}

Copyright for this article is retained by the author(s), with first publication rights granted to the journal.

This is an open-access article distributed under the terms and conditions of the Creative Commons Attribution license (http://creativecommons.org/licenses/by/3.0/). 